Research Article

\title{
Variance in multidimensional competencies and professional development needs of kindergarten teachers
}

\author{
Phoebe L. Gallego ${ }^{1}$ and Manuel E. Caingcoy ${ }^{2}$ \\ ${ }^{1}$ Department of Education Division of Sultan Kudarat, Philippines; ${ }^{2}$ Bukidnon State University, Philippines
}

\begin{abstract}
This paper investigated the variation in the multidimensional competencies and professional development needs of kindergarten teachers using a cross-sectional research design. It involved 54 purposively selected kindergarten teachers and collected the data using the self-assessment tool adopted by the Department of Education from the National Research Center for Teacher Quality in the Philippines. These data were analyzed using both descriptive and inferential statistics. As found, kindergarten teachers have a high level of competencies across dimensions. Also, they have a very high extent of professional development needs in content knowledge and pedagogy and the learning environment and diversity of learners. Moreover, they have a high extent of professional needs in two dimensions. The reported high priorities for training imply more emphasis on providing them professional development activities. Results found no significant difference in the competencies of kindergarten teachers in terms of age, position, civil status, degree, and years of teaching. On the contrary, significant differences revealed in their competencies in content knowledge and pedagogy, learning environment and learners' diversity, and curriculum and planning between those with masters and without a master's degree. Lastly, results show no significant difference in their professional development needs. These results have implications for future research and planning for a more responsive and costeffective professional development initiatives in the locale.
\end{abstract}

Keywords: Competencies, professional development needs, variances, comparative method

\section{Introduction}

In recent years, investigating the competencies of teachers have received an overwhelming attention among researchers (Ghavifekr \& Rosdy, 2015; Lucenario et al., 2016; Lee, 2011; Sawari, 2014; Selvi, 2016; Zamri \& Hamzah, 2019; Zhang \& Chicago, 2015;) including their professional development (Guskey, 2013; Lee, 2011; Sağır, 2014; Tanang \& Abu, 2014). Yet, there was a minimal attention given on comparing competencies and professional development needs of teachers or whether these competencies would significantly differ when teachers are grouped according to their age, gender, position, civil status, highest educational attainment, and the years of teaching. Much can be explored on prioritizing specific groups for professional development to rationalize initiatives. In taking this direction, it is interesting to ensure costeffective and more responsive professional development to the needs of teachers. Limitedly, previous research investigated these topics but not in the context of kindergarten.

A few comparative studies have evidence that teachers' competencies significantly differ when they are clustered. As reported, teachers at different ages perceived their pedagogical content knowledge competencies differently (Jeerapattanatorn, 2018). Moreover, teachers whose age was

Address of Corresponding Author

Phoebe L. Gallego, Department of Education Division of Sultan Kudarat, 9805, Philippines.

$\triangle$ phoebelgallego@gmail.com

0000-0001-9814-7825

How to cite: Gallego, P. L. \& Caingcoy, M. E. (2021). Variance in multidimensional competencies and professional development needs of kindergarten teachers. International Journal of Didactical Studies $2(2)$, 101461. https://doi.org/10.33902/IJODS.2021271213 
below 25 years old had a significantly higher mean score in assessment literacy than those who were 40-49 years old. Thus, young teachers tend to be more knowledgeable than their counterparts in terms of developing assessment methods. Teachers in a higher age range were inclined to use externally prepared methods or the same methods, while the new teachers tended to develop assessment methods themselves (Hailaya, 2014). These suggest that younger teachers are more creative than their counterparts. On the other hand, teaching experience matters. This means that as years of service increase, teachers' competence in assessment increases as well (Tagele \& Bedilu, 2018). Scholars claimed that effective interventions for the development of content knowledge and pedagogy are the experiences of teachers in the teaching practice (Evens et al., 2015). An assertion states that competent teachers are those teachers with sufficient teaching experience (Noviyanti, 2018). These points suggest that as teachers get age, they would improve better than those who are new to the profession. Moreover, it was reported that expert teachers were found more proficient at creating an optimal classroom climate for learning. They are adept at monitoring student problems, assessing the level of understanding and progress, and providing much more relevant and useful feedback (Hattie, 2003).

It was also reported that teachers with postgraduate qualifications had a significantly higher mean score in assessment literacy. These teachers tended to communicate assessment results more often than those without a higher degree (Hailaya, 2014). However, there was no significant difference in the technological pedagogical content knowledge of teachers when they were grouped in terms of age (Demirok \& Baglama, 2018). Also, empirical evidence indicates no significant difference in the teaching standards competence of teachers who are grouped according to marital status (Roberto \& Madrigal, 2018).

Much of the empirical evidence above was on competencies and none had been reported on the professional development needs of teachers. Previous evidence needs corroboration with more recent findings from the field. Among the existing studies, none was involving kindergarten teachers. And so, this is a good reason that the present research sets its trajectory on whether or not competencies and professional development needs of kindergarten teachers in the locale differ based on profiles. Answer to this question may aid the decision-makers and planners in prioritizing specific groups in involving teachers for future professional development initiatives. Also, it would help training developers to come up with more cost-effective initiatives for the professional development of these teachers.

Primarily, the present study is anchored on Philippine Professional Standards for Teachers or known as PPST which was developed by the Philippine National Research Center for Teacher Quality in 2017. These standards were adopted by the Commission on Higher Education and the Department of Education for teacher development and training. Specifically, the study is founded on domain seven which is on personal growth and professional development. This domain emphasizes the importance of proper and high regard for the teaching profession through maintaining the qualities that support the dignity of teaching career. Also, it underscores the value of professional reflection and continual learning. Thus, teachers are expected to embrace lifelong learning (PNRCTQ, 2017). Among the aims of PPST is to assess regularly the competencies of teachers including their needs for professional development. The trajectory of this paper supports the said intention. As has been argued, "the educators are expected to have a great deal of professional and personal qualities, and extraordinary skills" (Asio \& Riego de Dios, 2019, p. 126).

This paper was carried out and tested the following hypotheses:

1) There is no significant difference in the level of competencies of kindergarten teachers when they are grouped according to age, civil status, position, highest educational attainment, and years of teaching $\left(\mathrm{Ho}_{1}\right)$; and

2) There is no significant difference in the extent of the professional development needs of kindergarten teachers when they are grouped according to age, civil status, position, highest educational attainment, and years of teaching $\left(\mathrm{Ho}_{2}\right)$.

\section{Method}

\subsection{Research Design}

This paper employed cross-sectional design in determining the variation in the multidimensional competencies and professional development needs of kindergarten teachers using age, civil status, position, highest educational attainment, and years of teaching experience. It was conducted at President Quirino and Lamabyong Elementary Schools, Sultan Kudarat Division. Accordingly, "a cross-sectional study is a type of observational study design that involves looking at data from a 
population at one specific point in time" (Wang \& Cheng, 2020, p.565). They said that design has a number of strengths such as it is quick and inexpensive to conduct, no ethical difficulties, data on all variables are collected once, and its findings maybe made bases in conducting an in-depth research (Wang $\&$ Cheng, 2020). This design does not have strict assumptions to satisfy in terms of sampling, randomization, equal groupings for comparison, control, and among others.

\subsection{Participants}

The study involved 54 purposively selected kindergarten teachers including the substitutes during the survey. Most of them were graduates of the Bachelor in Elementary Education. A few had master's degrees. Also, a few have earned units in early childhood education. Table 1 shows the demographic of the respondents.

Table 1

Demographic Profile of the Respondents

\begin{tabular}{llcc}
\hline Profile & Groups & Frequency & Percentage \\
\hline Age & & 11 & 20.37 \\
\hline & 30 \& below & 22 & 40.75 \\
\hline & $31-37$ & 9 & 16.66 \\
\hline Civil status & $38-44$ & 12 & 22.22 \\
\hline & 45 \& above & 7 & 12.96 \\
\hline & Single & 47 & 87.04 \\
\hline Current position & Married & 31 & 57.41 \\
\hline & Teacher I & 27.78 \\
\hline & Teacher II & 15 & 14.81 \\
\hline $\begin{array}{l}\text { Educational } \\
\text { attainment }\end{array}$ & Teacher III & 8 & 88.89 \\
\hline & & & 11.11 \\
\hline Years of experience & Without masters & 48 & 64.82 \\
\hline & With masters & 6 & 35.18 \\
\hline & < years & 35 & \\
\hline & $<5$ years & 19 & \\
\hline
\end{tabular}

\subsection{Instrument}

The study employed the self-assessment tool intended for teachers I, II, and III. It was adopted by the Department of Education - Bureau of Human Resource and Organizational Development (2017) from Philippine Professional Standards for Teachers (PPST) developed by the National Research Center for Teacher Quality (PNRCTQ) in the Philippines in 2017. The tool has 12 indicators and four dimensions or domains namely the content knowledge and pedagogy, learning environment and diversity of learners, curriculum and planning, and the assessment and reporting. This tool underwent a process of validation when the PPST was developed by the PNRCTQ. This tool was also validated by experts from the academe. The first column of the tool identified the level of competencies of kindergarten teachers while the second column determined their professional development needs.

\subsection{Data Analysis}

Mean and standard deviation were used in determining the competencies and professional needs of kindergarten teachers. Variation in competencies and professional development needs was analyzed using analysis of variance (ANOVA) and the t-test for independent samples. Participants' age, civil status, current position, educational attainment, and years of teaching experience were used to compare their competencies and professional needs. These parameters are shown in Table 1. 


\section{Results and Discussion}

\subsection{Competencies and Professional Development Needs}

Developing the competencies of kindergarten teachers is essentially vital. With these, the quality of teaching and learning would improve. Table 2 presents the competency level of kindergarten teachers in the four domains. Results fall within a high level, which suggests that kindergarten teachers possessed most of the competencies of efficient teachers. Their level of competencies in assessment and reporting yielded the highest mean. This is followed by their competencies in content knowledge and pedagogy, then, curriculum and planning.

Table 2

Competencies of Kindergarten Teachers in Four Dimensions

\begin{tabular}{lccc}
\hline Domains & Mean & SD & Qualitative Description \\
\hline Assessment and Reporting & 3.76 & 0.39 & High \\
Content Knowledge and Pedagogy & 3.47 & 0.39 & High \\
Curriculum and Planning & 3.43 & 0.43 & High \\
Learning Environment and Diversity of Learners & 3.40 & 0.43 & High \\
\hline Overall & 3.52 & 0.41 & High \\
\hline
\end{tabular}

The results indicate that kindergarten teachers are more competent in assessing their learners, on what tools they should use during the assessment, as well as, they are reliable when they assess and when they give feedback to their learners, parents, and their stakeholders. These may be ascribed to many factors which may include their years of service and experiences. These results support the claim of Tagele and Bedilu (2018) that teaching experience matters. As years of service increase, teachers' competence in assessment increases. Further, the findings of the current study confirm that the participants have adequate competencies in all domains. These results would somehow debunk what was raised by Tlale (2013) that lack of knowledge, experiences, and expertise are the barriers in helping learners who have difficulties in class. This would imply that these teachers may encounter minor difficulties in teaching for they claimed they have a reasonable level of competencies in all domains.

Table 3 presents the professional development needs of kindergarten teachers. The results reveal that the extent of professional development needs of kindergarten teachers in the four competencies falls within the very high level, which suggests that they have a high priority for intensive and extensive continuing professional development. These results suggest that the participants still want to enrich their competencies, especially on the learning environment and diversity of learners as well as in content knowledge and pedagogy. These domains can be given more emphasis in the training design.

These results may suggest as well that they value life-long and continuing learning. Partly, these implications support the findings of Inbar-Lourie (2008) that teachers seek professional development programs regarding assessment. Also, the findings support the claim of Tagele et al. (2018) who claimed that teachers still need professional assistance and guidance in educational assessment methods. Although assessment and reporting turned out to be of less priority among these teachers, the extent still implies that it can be considered in the professional development plan and activities in the locale. Moreover, participating in continuous professional development is the key to boosting teachers' competence in the learning environment and diversity of learners. This assumption supports earlier claim that teachers should participate in educational seminars and workshops, read educational reading materials and engage in educational research as a form of professional development to be equipped with and supported in transforming the learning environment for the diverse needs of learners (Mitchell et al., 2017; SEAMEO Innotech Regional Education Program, 2010; Simonsen et al., 2020).

Table 3

Professional Development Needs of Kindergarten Teachers in Four Dimensions

\begin{tabular}{lccc}
\hline Domains & Mean & SD & Qualitative Description \\
\hline Learning Environment and Diversity of Learners & 4.70 & 0.39 & Very High \\
Content Knowledge and Pedagogy & 4.64 & 0.39 & Very High \\
Curriculum and Planning & 4.40 & 0.36 & High \\
Assessment and Reporting & 3.87 & 0.44 & High \\
\hline Overall & 40.40 & 0.39 & Very High \\
\hline
\end{tabular}




\subsection{Variances in the Multidimensional Competencies}

F statistics in Table 4 revealed that there were no significant differences in the level of competencies of these teachers in content knowledge and pedagogy, learning environment and learners' diversity, curriculum and planning as well as in assessment and reporting. These results indicate that regardless of how young or old these teachers are; it does not give them an advantage or make them disadvantaged. Thus, their competencies are at the same level. What the younger kindergarten teachers are capable of doing, then, the older ones are also capable of doing, or vice versa. Kindergarten teachers may have acquired more or less the same updates within the division or at the regional and national levels in all these areas of the curriculum. The results confirm the previous findings in which there was no significant difference in the Technological Pedagogical Content Knowledge levels of teachers when they were grouped in terms of age (Demirok \& Baglama, 2018). This was the case of special education teachers. In contrast, Jeerapattanatorn (2018) reported that business teachers with different ages perceived their pedagogical content knowledge competencies differently. This allowed the researchers to accept the alternative hypothesis. In another study, teachers whose ages were below 25 years old had a significantly higher mean score in assessment literacy than those ages between 40 and 49 years old. In this result, young teachers tend to be more knowledgeable than their counterparts in terms of developing assessment methods. Teachers in a higher age range were inclined to use externally prepared methods or the same methods, while the new teachers tended to develop assessment methods themselves (Hailaya, 2014). These simply suggest that younger teachers do not rely on ready-made assessment tools. It appeared that they are more creative than their counterparts.

T-test for independent samples revealed that there was no significant difference in the level of competencies between single and married kindergarten teachers, specifically in content knowledge and pedagogy, learning environment and learners' diversity, curriculum and planning, and in assessment and reporting. The level of their competencies of kindergarten teachers is not dependent on their civil status. Whether they are single or married, this cannot be a differentiating factor of their competencies. What the married teachers can do, the singles ones are also capable of doing or vice versa. Thus, both groups have the competencies of efficient teachers. These results confirm the previous empirical evidence that found no significant difference in the teaching standards competence of teachers grouped according to marital status (Roberto \& Madrigal, 2018).

$\mathrm{F}$ statistics revealed that there was no significant difference in the competencies of teachers across current positions. These results indicate that the level of competencies of kindergarten teachers was not dependent on their current position. The results in table 5 imply also that kindergarten teachers' position is not an advantage or a disadvantage when it comes to possessing the capabilities of efficient teachers. Conversely, it was reported that expert teachers were found more proficient at creating optimal classroom climate for learning, adept at monitoring student problems, and assessing their level of understanding and progress, and in providing much more relevant and useful feedback to learners (Hattie, 2003).

Table 4

Variances in the Multidimensional Competencies of Kindergarten Teachers

\begin{tabular}{|c|c|c|c|c|}
\hline Variables & $\begin{array}{c}\text { Content } \\
\text { Knowledge } \\
\text { Pedagogy }\end{array}$ & $\begin{array}{c}\text { Learning } \\
\text { Environment } \\
\text { And Learners } \\
\text { Diversity }\end{array}$ & $\begin{array}{l}\text { Curriculum and } \\
\text { Planning }\end{array}$ & $\begin{array}{c}\text { Assessment and } \\
\text { Reporting }\end{array}$ \\
\hline Age & $\begin{array}{c}F(d f)=1.264 \\
p=.297\end{array}$ & $\begin{array}{c}\mathrm{F}(\mathrm{df})=.338 \\
\mathrm{p}=.798\end{array}$ & $\begin{array}{c}\mathrm{F}(\mathrm{df})=1.323 \\
\mathrm{p}=.277\end{array}$ & $\begin{array}{c}\mathrm{F}(\mathrm{df})=1.235 \\
\mathrm{p}=.307\end{array}$ \\
\hline Civil Status & $\begin{array}{c}t(d f)=2.13 \\
p=.664\end{array}$ & $\begin{array}{c}t(\mathrm{df})=2.06 \\
\mathrm{p}=.434\end{array}$ & $\begin{array}{c}t(d f)=2.18 \\
p=.689\end{array}$ & $\begin{array}{c}t(d f)=3.30 \\
p=.626\end{array}$ \\
\hline Current Position & $\begin{array}{c}F(d f)=1.059 \\
p=.354\end{array}$ & $\begin{array}{c}F(d f)=.218 \\
p=.805\end{array}$ & $\begin{array}{c}F(d f)=.382 \\
p=.685\end{array}$ & $\begin{array}{c}\mathrm{F}(\mathrm{df})=.134 \\
\mathrm{p}=.875\end{array}$ \\
\hline $\begin{array}{l}\text { Educational } \\
\text { Attainment }\end{array}$ & $\begin{array}{c}t(d f)=-2.48 \\
p=.016^{*}\end{array}$ & $\begin{array}{c}t(d f)=-3.56 ; \\
p=.001^{*}\end{array}$ & $\begin{array}{c}t(d f)=-2.48 \\
p=.016^{*}\end{array}$ & $\begin{array}{c}t(d f)=-1.55 \\
p=.126\end{array}$ \\
\hline $\begin{array}{l}\text { Years of } \\
\text { Experience }\end{array}$ & $\begin{array}{c}t(d f)=-1.44 \\
p=.153\end{array}$ & $\begin{array}{c}t(d f)=-.828 \\
p=.411\end{array}$ & $\begin{array}{c}t(d f)=-887 \\
p=.379\end{array}$ & $\begin{array}{c}t(d f)=-1.04 \\
p=.302\end{array}$ \\
\hline
\end{tabular}

Notes: ${ }^{*} p$ value is significant at 0.05 level 
Also, t-test statistics revealed significant differences in the level of competencies of kindergarten teachers with a master's degree and without master's degrees. Specifically, these differences were revealed in content knowledge and pedagogy, learning environment and learners' diversity, and curriculum and planning (see Table 6). Moreover, it was unveiled that there was no significant difference in the level of competencies of kindergarten teachers when they were clustered based on years of teaching experience.

Explicitly, those teachers with master's degrees are far more competent than their counterparts. However, there was no significant difference in the level of their competence in assessment and reporting. This contradicts previous findings that teachers with postgraduate qualifications had a significantly higher mean score in assessment literacy. This report implied that these teachers tended to communicate assessment results more often than those without a higher degree (Hailaya, 2014).

Longer years of teaching experience does not give teachers an advantage in developing these competencies. This is contradictory to the previous results that those teachers with 1-5 years of teaching experience had significantly higher mean score with those who had 11-15 years, and those who had 21-25 years. Those with very short teaching experience are more competent in the assessment. However, those whose teaching experience within 6-10 years had a higher mean score over those with 1-5 years and with 16 to 20 years of teaching experiences. Thus, the former teachers are more assessment literate or competent than their counterparts (Hailaya, 2014). Results also contradicted an assertion that teachers' teaching experiences are continually expanding and developing teachers' competence in pedagogical content knowledge (Lee, 2011). The first null hypothesis that states, there is no significant difference in the level of competencies of kindergarten teachers when they are grouped according to profile, was rejected since those who have master's degrees are more competent than their counterpart.

\subsection{Variances in the Multidimensional Professional Development Needs}

Results in Table 5 revealed that there are no significant differences in the professional needs of kindergarten teachers across ages, current positions, teaching experiences or between married and single, and with and without master's degrees, specifically in the content knowledge and pedagogy, learning environment and diversity of learners, curriculum and planning as well as in assessment and reporting.

Regardless of age, current positions, years of teaching experience, engagement in graduate studies, whether single or married, these kindergarten teachers have the same extent of priority for further training for professional development. Unfortunately, there were no studies that can support or contradict these empirical findings. There is more to discover on these areas. Future researchers may investigate further if the professional needs of teachers would significantly vary across age groups, positions or ranks, a range of length of experience in teaching, and among those who obtained higher degrees and their counterparts.

In reality, our education system keeps on changing and updating. And so, the years of teaching experience cannot make any marginal advantage over those who are just new to the teaching profession. As to personal observation, many of the new breeds of graduates are enrolling in postgraduate studies. This may be one reason why they were able to catch up with updates and new trends. The results contradict the claim that effective interventions for the development of content knowledge and pedagogy are the experiences of teachers in the teaching practice (Evens et al., 2015) and the competent teachers are those teachers with sufficient teaching experience (Noviyanti, 2018). With these results, the second null hypothesis that reads, there is no significant difference in the extent of the professional development needs of kindergarten teachers when they are grouped according to profile, was accepted. This was because there was no evidence that their profile can yield significant variances in their professional development needs.

\section{Conclusion}

The independent variables such as age, civil status, position, and the years of teaching experience cannot guarantee a more advanced level of competencies in content knowledge and pedagogy, learning environment and diversity of learners, and curriculum and planning. However, it turned out that those teachers with master's degrees are more competent in content knowledge and pedagogy, learning environment, and diversity of learners as well as in curriculum and planning 
Table 5

Variances in the Multidimensional Professional Development Needs of Kindergarten Teachers

\begin{tabular}{|c|c|c|c|c|}
\hline Variables & $\begin{array}{c}\text { Content } \\
\text { Knowledge } \\
\text { Pedagogy }\end{array}$ & $\begin{array}{c}\text { Learning } \\
\text { Environment } \\
\text { And Learners } \\
\text { Diversity }\end{array}$ & $\begin{array}{l}\text { Curriculum and } \\
\text { Planning }\end{array}$ & $\begin{array}{c}\text { Assessment and } \\
\text { Reporting }\end{array}$ \\
\hline Age & $\begin{array}{c}F(d f)=1.691 \\
p=.181\end{array}$ & $\begin{array}{c}F(d f)=1.223 \\
p=.311\end{array}$ & $\begin{array}{c}F(d f)=.626 \\
p=.601\end{array}$ & $\begin{array}{c}F(d f)=.534 ; \\
p=.661\end{array}$ \\
\hline Civil Status & $\begin{array}{c}t(\mathrm{df})=-.211 \\
\mathrm{p}=.834\end{array}$ & $\begin{array}{c}t(\mathrm{df})=1.04 \\
\mathrm{p}=.300\end{array}$ & $\begin{array}{c}t(\mathrm{df})=-.945 \\
\mathrm{p}=.349\end{array}$ & $\begin{array}{c}t(\mathrm{df})=.823 \\
\mathrm{p}=.414\end{array}$ \\
\hline Current Position & $\begin{array}{c}F(d f)=.746 \\
p=.479\end{array}$ & $\begin{array}{c}\mathrm{F}(\mathrm{df})=.151 \\
\mathrm{p}=.860\end{array}$ & $\begin{array}{c}\mathrm{F}(\mathrm{df})=.773 \\
\mathrm{p}=.467\end{array}$ & $\begin{array}{c}F(d f)=.568 \\
p=.629\end{array}$ \\
\hline $\begin{array}{l}\text { Educational } \\
\text { Attainment }\end{array}$ & $\begin{array}{c}t(d f)=.972 \\
p=.336\end{array}$ & $\begin{array}{l}\mathrm{t}(\mathrm{df})=1.375 ; \\
\mathrm{p} \text { value }=.175\end{array}$ & $\begin{array}{c}t(d f)=1.747 \\
p=.807\end{array}$ & $\begin{array}{c}t(d f)=-1.782 \\
p=.081\end{array}$ \\
\hline $\begin{array}{l}\text { Years of } \\
\text { Experience }\end{array}$ & $\begin{array}{c}\mathrm{t}(\mathrm{df})=.227 \\
\mathrm{p}=.821\end{array}$ & $\begin{array}{c}t(d f)=-.370 \\
p=.713\end{array}$ & $\begin{array}{c}t(d f)=-1.256 \\
p=.215\end{array}$ & $\begin{array}{c}t(d f)=-292 \\
p=.771\end{array}$ \\
\hline
\end{tabular}

Notes: * $p$ value is significant at 0.05 level

than their counterparts. But this significant difference was not true in their competencies in assessment and reporting. Regardless of age, position, civil status, educational attainment, and years of teaching, the extent of the professional development needs of kindergarten teachers do not significantly differ. This study had encountered these limitations. One, it tested hypotheses yet the sample was not randomly selected. Two, it has small sample. This was due to a small population of kindergarten teachers in the locality. Selecting a sample through randomization was not possible.

The results have implications for future research to further this trajectory and find out additional evidence on the variation of professional development needs. Another option for future research is to investigate whether competencies of kindergarten or early childhood teachers across regions have comparable standards. This requires another comparative study and cross-sectional analysis. Also, the results have implications for future planning for a more responsive and costeffective professional development initiatives in the locale. This study acknowledged that there was very limited literature that could support the results, especially on no variation in the professional development needs of kindergarten teachers.

\section{References}

Asio, J. M. R., \& de Dios, E. E. R. (2019). The college students' perspective on what makes an educator wellqualified. Journal of Pedagogical Research, 3(3), 126-138. https://doi.org/10.33902/.jpr.v3i3.124

Demirok, M.S., \& Baglama, B. (2018). Examining Technological and Pedagogical Content Knowledge of Special Education Teachers Based on Various Variables. TEM Journal, 7 (3), 507-512. http://dx.doi.org/10.18421/TEM73-06

Department of Education - Teacher Education Council. (2017). Philippine Professional Standards for Teachers. DepEd. https://bit.ly/30W1ocr

Evens, M., Elen, J., \& Depaepe, F. (2015). Developing Pedagogical Content Knowledge: Lessons Learned from Intervention Studies. Education Research International, (1), 1-23. https://doi.org/10.1155/2015/790417

Ghavifekr, S., \& Rosdy, W. A. W. (2015). Teaching and Learning with Technology: Effectiveness of ICT Integration in Schools Teaching and Learning with Technology: Effectiveness of ICT Integration in Schools. International Journal of Research in Education and Science, 1(2), 175-191.

Guskey, T. R. (2013). Does It Make a Difference? Evaluating Professional Development. ASCD, 59(6), 45-51. https://www.ascd.org/el/articles/does-it-make-a-difference-evaluating-professional-development

Hailaya, W. M. (2014). Teacher Assessment Literacy and Student Outcomes in the Province of Tawi-Tawi, Philippines. University of Adelaide. http://hdl.handle.net/2440/99098

Hattie, J. A. C. (2003). Teachers make a difference: What is the research evidence? Paper presented at the Building Teacher Quality: What does the research tell us. ACER Research Conference, Melbourne, Australia. https:// bit.ly/308LD2J

Inbar-Lourie, O. (2008). Constructing a language assessment knowledge base: A focus on language assessment courses. Language Testing, 25(3), 385-402. https://doi.org/10.1177/0265532208090158

Jeerapattanatorn, P. (2018). Competencies in Pedagogical Content Knowledge of Business Teachers in Thailand's Vocational School: A Synthesis under 21st Century Education Framework. International 
Journal of Management and Applied Science, 4(2), 110-115. http://iraj.doionline.org/dx/IJMAS-IRAJDOIONLINE-11095

Lee, Y. (2011). Enhancing pedagogical content knowledge in a collaborative school-based professional development program for inquiry-based science teaching. Asia-Pacific Forum on Science Learning and Teaching, 12(2), 1-29. https://doi.org/10.1155/2015/790417

Lucenario, J.L. S., Yangco, R. T., Punzalan, A.E., \& Espinosa, A. A. (2016). Pedagogical Content KnowledgeGuided Lesson Study: Effects on Teacher Competence and Students 'Achievement in Chemistry. Hindawi Publishing Corporation Education International. https://doi.org/10.1155/2016/6068930

Mitchell, B. S., Hirn, R. G., \& Lewis, T. J. (2017). Enhancing Effective Classroom Management in Schools. Teacher Education Division of the Council for Exceptional Children, 40(2), $140-153$. https: / / doi.org/https://doi.org/10.1177/0888406417700961

Noviyanti, M. (2018). An Analysis of Teachers' Pedagogical Content Knowledge on Number Sense Learning of Early Childhood. American Journal of Humanities and Social Sciences Research, 2(11), $137-142$. http:/ / www.ajhssr.com/wp-content/uploads/2018/11/Q18211137142.pdf

Philippine National Research Center for Teacher Quality [PNRCTQ] (2017). Philippine Professional Standards for Teachers. PNRCTQ.

Roberto, J., \& Madrigal, D. (2018). Teacher Quality in the Light of the Philippine Professional Standards for Teachers. Philippine Social Science Journal, 1(1), 67-80. https://doi.org/10.52006/main.v1i1.13

Sağır, M. (2014). Teachers Professional Development Needs and the Systems That Meet Them. Creative Education, 5, 1497-1511. DOI: 10.4236/ce.2014.516167

Sawari, S. S. M. (2014). Teacher Competency Assessment in the Classroom: Current Issues Teacher Competency Assessment in the Classroom: Current Issues. International Journal of Informative and Futuristic Research, 1(3), 90-96.

SEAMEO Innotech Regional Education Program. (2010). Teaching Competency Standards of Southeast Asian Countries: Eleven Country Audit (Vol. https://www.seameo.org/SEAMEOWeb2/images/stories/Publications/Centers_pub/2012TeachingComp etencyStandards/TeachingCompetencyStd.pdf

Selvi, K. (2016). Teachers' Competencies. International Journal of Philosophy of Culture and Axiology, 168175. https://www.academia.edu/2648770/Teachers_Competencies

Simonsen, B., Freeman, J., Myers, D., Dooley, K., Maddock, E., Kern, L., \& Byun, S (2020). The Effects of Targeted Professional Development on Teachers' Use of Empirically Supported Classroom Management Practices. Journal of Positive Behavior Interventions, $22 \quad(1), \quad 3-14$. https: / / doi.org/10.1177/1098300719859615

Tagele, A., \& Bedilu, L. (2018). Teachers' Competence in the Educational Assessment of Students: The Case of Secondary School Teachers in the Amhara National Regional State Students: The Case of Secondary School Teachers in the Amhara. The Ethiopian Journal of Education, 15, 163.

Tanang, H., \& Abu, B. (2014). Teacher Professionalism and Professional Development Practices in South Sulawesi, Indonesia. Journal of Curriculum and Teaching, 3(2), $25-42$. https://doi.org/10.5430/jct.v3n2p25

Tlale, L. D. N. (2013). Teachers' Competency in Responding to the Needs of Learners with Barriers to Learning. Mediterranean Journal of Social Sciences, 4(13), 143-148. DOI: 10.5901/mjss.2013.v4n13p143

Wang, X., \& Cheng, Z. (2020). Cross-Sectional Studies: Strengths, Weaknesses, and Recommendations. CHEST, 151(1), 565-571. https://doi.org/10.1016/j.chest.2020.03.012

Zamri, M. N. B., \& Hamzah, M. I. B. (2019). Teachers' Competency in Implementation of Classroom Assessment in Learning. Creative Education, 3(1), 2939-2946. DOI: 10.4236/ce.2019.1012218

Zhang, Y., \& Chicago, I. (2015). Pedagogical Content Knowledge in Early Mathematics: What Teachers Know and how it Associates with Teaching and Learning. ProQuest LLC. 